\title{
Teachers' Perception and Practice of Constructivist Teaching Approach: The Case of Secondary Schools of Kamashi Zone
}

\author{
Solomon Melesse* and Endalew Jirata
}

\author{
Faculty of Education and Behavioral Science, Bahir Dar University, P.O. Box: 79, Bahir Dar, Ethiopia
}

\begin{tabular}{|c|c|}
\hline Abstract & Article Information \\
\hline 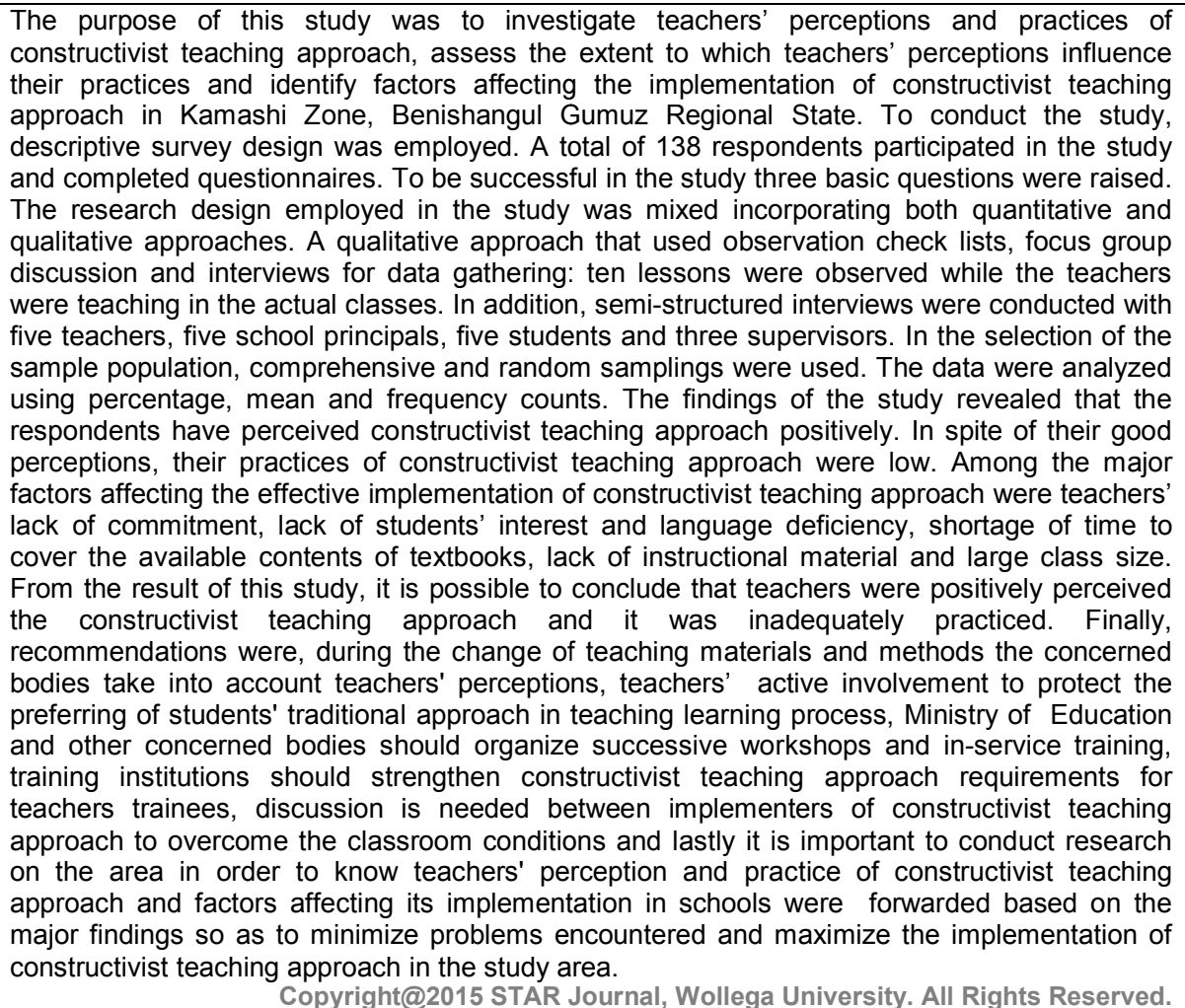 & $\begin{array}{l}\text { Received : 09-10-2015 } \\
\text { Revised : 22-12-2015 } \\
\text { Accepted : 28-12-2015 } \\
\text { Keywords: }\end{array}$ \\
\hline
\end{tabular}

\section{INTRODUCTION}

Education enables individuals and society to make allrounded participation in the development process by acquiring knowledge, ability, skills and attitudes. One of the aims of education is to strengthen the individuals and society's problem-solving capacity, ability and culture starting from basic education and at all levels. Education enables person to identify harmful traditions and replace them by useful ones. It helps human beings to improve, change, as well as develops and conserves the environment for the purpose of an all-rounded development by diffusing science and technology into the society. Education also plays a role in the promotion of respect for human rights and democratic values, creating the condition for equality, mutual understanding and cooperation among people. Education does not operate in isolation, rather it has to be integrated with research, practice and development to contribute to an all- rounded development of society (MOE, 1994).

To put the above benefits of education in effect, improving the quality of education has a par-amount importance (UNESCO, 2005). However, monitoring quality education to children attending in schools is not simple and an easy task. It requires several efforts and commitment of the different stakeholders and fulfillment of all the necessary provisions that a necessary for the work. In this respect, the teacher is the single most important factor either in facilitating or hindering the quality of 


\section{Solomon Melesse and Endalew Jirata}

education in the classroom. Moreover, in Ethiopia the 1994 education and training policy agreement possible to the employment of active teaching and learning approaches in schools. In addition curriculum reform was launched to demand teaching to effectively utilize active teaching strategies as one of the means to maintain quality education for students teaching in schools. In other words, the 1994 education policy of Ethiopia demands classroom teaching to be in line with the constructivist teaching approach, which is highly learner focused approach.

As indicated in ICDR (1999), the quality of education to a great extent depends on the quality of the teacher. This is particularly turn to secondary school students where most of the children are at the age of adolescents and not yet matured to learn well by themselves. This is to mean that students of this level require much support from both their teachers, school administrators, directors and other administrative staffs.

Moreover, in order to equip children with the most up to date scientific tricks in creative manner and to enable them to lead their future life in a better way, teachers should not only have the knowledge of the subject matter that they are assigned to teach but also the necessary skills of applying various strategies of teaching. This makes teaching both an art and science (Derbesa, 2004).

The art of teaching involves the creative as well as the practical ability to use various means of skills in a new way based on the situation of the learners in the classroom. On the other hand, the science of teaching practice and examining involves the ability to observe teaching practices and examining the ever growing knowledge in the field (Goge, 1978).

This fact in Ethiopia with the adaption of the 1994 current education policy an extensive change has been made to improve the educational system. One of this change is the paradigm shift in the model of teaching which involves a shift from the traditional teaching approach to active teaching approach .The implication of this is that Ethiopian education system requires teachers to have the necessary knowledge of the constructivist teaching approach. In constructivism, the learner is much more actively involved in constructing meanings. The emphasis is on the learner as an active maker of meanings, and the role of the teacher is to enter into a dialogue with the learner, and thereby help the learner to construct the meaning of the material to be learned. In the case of cognitive constructivism, the individual learner understands things in terms of developmental stages and learning styles. The philosophy of constructivism is associated with the writings of Dewey (1983) who emphasized the place of experience in education and the work of Piaget (1976), who demonstrated empirically that children's' minds are not empty vessels rather they actively process the material with which they are presented and postulate the mechanisms of accommodation and assimilation as key to this processing.

Since the theory of constructivism describes the process of meaning-making, in which individuals construct mental models that ground their understanding in a deeply personal and unique fashion, different schools in the world are using it in their instruction. Further, they employ it in
Sci. Technol. Arts Res. J., Oct-Dec 2015, 4(4): 194-199

the actual classroom believing that certain activities and environmental enrichments can enhance the meaning making process. These activities include using active learning through kinesthetic, visual and auditory modalities, creating opportunities for dialogue, fostering creativity and providing a rich, safe and engaging learning environment (Brooks and Brooks, 1992). Since constructivism is a learning theory describing the process of knowledge construction to create autonomous learner, the Ethiopian Education Policy strongly supports its practice in the classroom (TESO, 2003). In other words, the constructivist teaching approach allows students not only to receive information from their teacher but also to discuss, analyze, solve problems, present their ideas and opinions while teaching and learning is going on.

Nowadays, many countries in the world give much emphasis for constructivist method of teaching and learning. For example, in Ethiopia, much effort has been made for the last few years to make the students become competent in their academic performance, meaning construction and creativity. Moreover, it is also believed that constructivist approach of teaching must be strengthened in teacher education institutions to train teachers who can tackle problems from the sense of responsibility as professional practitioner. Accordingly, a nation-wide research was undertaken to survey the status and quality of training that has been given to primary and secondary school teachers (MOE, 1994). The study revealed that though teacher educators and teachers at different school levels had reasonably good academic knowledge, they lack skills in employing various teaching approaches (including assessment) that are set in the policy (MOE, 1994). The report also indicated that teaching institutions have been in problem to deliver good quality service at all levels as they followed set routines based on traditions, habit and traditional norms and expectations (TESO, 2003).

This by implication would mean that the perceptions and practice that teachers have about the constructivist teaching approach influences the way how teachers select and utilize different instructional approaches in the classroom .The major concern of this study, therefore, was to investigate teachers' perceptions and current practices of the constructivist teaching approach of secondary schools of Kamashi Zone, Benishangul Gumuz Regional State.

The Purpose of this study was to investigate teachers' perceptions and practices of constructivist teaching approach in secondary schools of Kamashi Zone, Benishangul Gumuz Regional State. To achieve the main purpose, the following specific objectives were formulated to assess teachers perception about the constructivist teaching approach, to investigate the extent of teachers applications of the constructivist teaching approach in secondary schools and to observe whether there are obstacles in implementing the constructivist teaching approach

\section{MATERIALS AND METHODS}

A study involving descriptive survey method was applied to collect the data.

\section{Source of Data}

The main source of data for this study was grade 10 students, teachers, school principals and supervisors in 
Solomon Melesse and Endalew Jirata

selected governmental secondary schools of Kamashi Zone, Benishangul Gumuz Regional State. The total number of the sample population was 138 respondents.

\section{Sample Size and Sampling Technique}

Kamashi Zone is one of the zones in Benshangul Gumuz Regional State. It has 5 woredas. There are 11 secondary schools. From the 11 secondary schools in the zone, only 5 secondary schools were selected by random sample technique because each woreda has equal
Sci. Technol. Arts Res. J., Oct-Dec 2015, 4(4): 194-199

number of secondary schools. The sample selected schools in the Zone were Enginer Tegre Deressa, Kamashi Boys and Boarding school, Agalo Meti, Yasso and Chigisha secondary schools. The total number of grade 10 students in the selected schools was 296 . Of these, only $89(30 \%)$ of the students and from the total number of 58 teachers only $41(70 \%)$ of them were selected by lottery method and 3 supervisors 5 directors were selected by comprehensive sampling technique.

Table 1: Summary of population, sample size and sampling techniques

\begin{tabular}{clccccccc}
\hline \multirow{2}{*}{ No } & Types of & \multicolumn{3}{c}{ Population Size } & \multicolumn{3}{c}{ Sample Size } & \multirow{2}{*}{ Sampling Technique } \\
\cline { 3 - 7 } & respondents & Male & Female & Total & Male & Female & Total nnn & \\
\hline 1 & Grade 10 Students & 222 & 74 & 296 & 74 & 15 & 89 & Random sampling \\
2 & Teachers & 51 & 7 & 58 & 36 & 5 & 41 & Random \\
3 & Supervisors & 3 & - & 3 & 3 & - & 3 & comprehensive \\
4 & School principals & 5 & - & 5 & 5 & - & 5 & comprehensive \\
\hline $\mathbf{5}$ & Total & $\mathbf{2 8 1}$ & $\mathbf{8 1}$ & $\mathbf{3 6 2}$ & $\mathbf{1 1 8}$ & $\mathbf{2 0}$ & $\mathbf{1 3 8}$ & \\
\hline
\end{tabular}

\section{Data Gathering Instruments}

Questionnaire, Interview and Classroom observation have been employed quantitatively and qualitatively respectively. A questionnaire for teachers and students including perceptions and practices of constructivist teaching approach was prepared (refer Appendix A and $B$ ). The questionnaire was developed from literature review that was composed of five likert scales type close ended items. In addition, items across each category were arranged under the rating scale with five points. These five points scale range from strongly agree $=5$, agree $=4$, undecided $=3$, disagree $=2$ and strongly disagree $=1$. Besides, data from interviews, and class observation were triangulated to validate the findings.

To minimize the potential misunderstanding the researcher first prepared the questionnaire in English and then translated it into Amharic for the students by the researcher. After the advisor rigorous comment on the items, the researcher reshaped the instruments. Eventually, some items were modified some were changed and added. Furthermore, to develop appropriate instrument for the study, the researcher administrated the pilot study at Diza secondary school to 13 teachers and 27 students by purposive sampling technique.

An interview is highly flexible and allowed for in depth questioning when properly planned structured and conducted. It can be a nice way of getting information about teachers' practices and the problem hindering towards constructivist teaching approach. Therefore, the researcher made interviews on certain points for some detailed information. The teachers and the students were selected by lottery method, the principals and supervisors were selected by comprehensive sampling. For this reason, 5 principals, 3 supervisors, 5 teachers and 5 students were interviewed.

The main purpose of class observation was to investigate the actual teaching learning process and to cross check the response of both teachers and students in the questionnaires. Furthermore, observation was used to see what teachers and students are really doing in the classroom. The researcher attempted to see whether the teacher used only the constructivist teaching approach by the nature of the lesson in the text book.

\section{Methods of Data Analysis}

As far as the quantitative data were concerned SPSS version 20 software was used for data entry and analysis. The frequency counts and one sample t-test was computed to explore the level of teachers perceptions, practices and the problem hindering of constructivist teaching approach. Interview, observation, were also used to analyze qualitatively to show teachers' actual classroom practices of constructivist teaching approach and factors that hinder the implementation of constructivist teaching approach.

\section{RESULTS AND DISCUSSION}

As can be seen in Table 2, the mean values of their responses were 4.10. Hence, most of the teachers supported the idea that teaching and learning process going on when there is interaction in the classroom. i.e., the teacher holds most of the knowledge necessary for the students and the teachers believe that students can also be sources of knowledge.

Table 2: The level of teacher's perceptions towards constructivist teaching approach

\begin{tabular}{|c|c|c|c|c|c|c|c|}
\hline $\mathbf{N}$ & Items & $\mathbf{N}$ & Mean & SD & $\mathbf{t}$ & df & $\begin{array}{l}\text { Sig-2 } \\
\text { tailed }\end{array}$ \\
\hline 1 & Students learn when there is interaction & 41 & 4.10 & 0.889 & 7.906 & 40 & .000 \\
\hline 2 & $\begin{array}{l}\text { Learning becomes effective when teacher asses and provide } \\
\text { feedback to each individual learner in the classroom }\end{array}$ & 41 & 3.93 & 1.010 & 5.878 & 40 & .000 \\
\hline 3 & $\begin{array}{l}\text { Encouraging learner to learn dialogue during instruction increase } \\
\text { their retention of the lesson }\end{array}$ & 41 & 3.98 & 0.689 & 9.070 & 40 & .000 \\
\hline 4 & CTA makes students responsible for their own learning & 41 & 4.05 & 0.773 & 8.687 & 40 & .000 \\
\hline 5 & $\begin{array}{l}\text { Applying cognitive terminologies such as analyze and synthesize in } \\
\text { classroom instruction increase the learners problem solving capacity }\end{array}$ & 41 & 4.12 & 0.748 & 9.602 & 40 & .000 \\
\hline 6 & $\begin{array}{l}\text { The CTA is an effective teaching approach to develop students } \\
\text { learning }\end{array}$ & 41 & 4.15 & 41 & 9.654 & 40 & .000 \\
\hline
\end{tabular}




\section{Solomon Melesse and Endalew Jirata}

As the data indicates for item no 2, most of the respondents with the mean value of 3.93 recognized the provision of continuous follow up and feedback to the learners during instruction as an important issue in increasing the students' academic success. In this regard, Derebsa (2004) providing feedback, like for example, cograduating students for having done well at self initiated educational activities may promote a feeling of motivation and increases their school performance.

As it is shown in Table 2, for item no 3, the mean value for this item was 3.98 which were still relevantly high. As the data indicates the majority of respondents believe that dialogue creates competition among peers, the need to achieve something by overcoming barriers to sure pass the successes of others. Dialogue enables the learners to develop the ability to share information in solving problems. Supporting this idea, Murnane, and Willet, (2010), expressed that dialogue sustain students to strive to get satisfying academic success in school.

The result for item no 4, in Table 2, indicates that the majority of respondents with the mean value of 4.05 promote the idea those students must have the willingness to take responsibility for their own learning. Supporting this idea, Curickshank (1995), noted that "students should be encouraged to learn by their own rather than given or seeking information as in the case with receptive learning and expository teaching with highly considers the teacher as only bank of knowledge".

To item no 5 in Table 2, the respondents with the mean value of 4.32 said that involving students to participate in analysis and synthesis levels of taught
Sci. Technol. Arts Res. J., Oct-Dec 2015, 4(4): 194-199

increases their problem solving capacity. Those interviewed also disclosed that most of the teachers have better understanding of the importance of the above cognitive terms in increasing the learners' problem solving capacity. As clearly seen from Table 2 , item no 6 , the mean value was 4.15 which are relatively high. When teachers have better understanding about the effectiveness of constructivist teaching approach in developing students learning, it is very likely that teachers will make greater effort to put into effect the intended outcome successfully, on contrary, if teachers have less understanding about its effectiveness, they will not be sustained to accomplish the task in an intended ways. In this regard, Lea, et al. (2003), stated the learner focused constructivist teaching approach as an effective teaching approach because of its reliance on increased sense autonomy in the learner and interdependence between the teacher and the learner.

As indicated in Table 3, except six (14.6\%) of the respondents, the majority $35(85.4 \%)$ of the respondents disclosed the idea that class size is an obstruct to the implementation of constructivist teaching approach. Research conducted in developing countries suggests that, smaller classes are better than large classes .In fact, within the research into large classes, at least two factors have been identified as more important than class size: firstly, the quality of teaching and secondly the kinds of activities used. Large classes are one of the principle reasons which maintain the traditional teacher- centered approach to learning as ineffective and prevents the implementation of any team work that is indicative of the constructivist teaching approach.

Table 3: Teachers' response about problems affecting the implementation of the constructivist teaching approach

\begin{tabular}{|c|c|c|c|}
\hline No & Question provided for teachers & $\begin{array}{c}\text { No of } \\
\text { respondents }\end{array}$ & $\begin{array}{c}\% \text { of } \\
\text { respondents }\end{array}$ \\
\hline 1 & $\begin{array}{l}\text { Do you think that large class size can be the problem of implementation? } \\
\text { A. Yes } \\
\text { B. No }\end{array}$ & $\begin{array}{c}35 \\
6\end{array}$ & $\begin{array}{l}85.4 \% \\
14.6 \%\end{array}$ \\
\hline
\end{tabular}

To item no 1 in Table 4, the mean value (2.20) shows a low value. As the data shows, most of the respondents reported that their teachers do not encourage and give opportunities for students to expand their knowledge by developing and testing hypotheses other than merely listening or reading to the teacher. In contrary to this idea, Brumer, cited by Brophy (1989), suggested that in order to lead meaningful learning by involving students in exploration motivated by curiosity, teachers need to use instructional approach that encourages guided discovery.

Table 4: Student response towards the actual practice of constructivist teaching approach

\begin{tabular}{|c|c|c|c|c|c|c|c|}
\hline $\mathbf{N}$ & Item related to practice of constructivist teaching & $\mathbf{N}$ & Mean & SD & $\mathbf{t}$ & df & $\begin{array}{l}\text { Sig-2 } \\
\text { tailed }\end{array}$ \\
\hline 1 & $\begin{array}{l}\text { Teachers encourage the learner to discover and describe } \\
\text { instructional phenomena. }\end{array}$ & 89 & 2.20 & 1.099 & -6.846 & 88 & .000 \\
\hline 2 & $\begin{array}{l}\text { Teachers create a question reach learning environment during } \\
\text { instruction. }\end{array}$ & 89 & 3.43 & 1.296 & 3.108 & 88 & .003 \\
\hline 3 & $\begin{array}{l}\text { Teachers provide individual activities that enhance student } \\
\text { participation during the classroom teaching learning process. }\end{array}$ & 89 & 3.31 & 0.834 & 3.559 & 88 & .001 \\
\hline 4 & Teachers make pupils work with materials and activities & 89 & 3.37 & 0.993 & 3.523 & 88 & .001 \\
\hline 5 & Teachers allow wait time to the learners after posing questions & 89 & 2.49 & 1.159 & -4.115 & 88 & .000 \\
\hline 6 & $\begin{array}{l}\text { When children engage or work in classroom activities, the teacher } \\
\text { assess and provides minimal help for individual learners. }\end{array}$ & 89 & 1.99 & 1.082 & -8.818 & 88 & .000 \\
\hline
\end{tabular}

For item no 2 of Table 4, above, the majority of the respondents with the mean value for this item was 3.43 which is relatively high. As can be seen from the data, most of the respondents replied that their teachers maintain conductive or democratic environment for the prevalence of interactive questioning during classroom teaching and learning process. Supporting this idea, Dalton (1981) cited by Brophy (1989) further advised teachers expressing the idea that in order to maintain a question reach learning environment, teachers must avoid 


\section{Solomon Melesse and Endalew Jirata}

unnecessary behaviors such as cutting of students comment or questions with irritation or responding in a manner that make students sorry. These scholars also further explained that teachers must avoid negative feedback such as unnecessary intervention, nagging, insulting and others which may hinder or stop students to ask or to respond questions.

As it is shown in Table 4 for item no 3 , the majority of the respondents with the mean value of 3.31 indicate that teachers provide individual activities or assignments to enhance their participation in learning the classroom lessons successfully. Supporting this idea, Davis (1981) also expressed providing individual assignment for students is important to understand their strength and weakness by enabling them to receive feedback on how well or badly they are doing it.

For item no 4 of Table 4 , the respondents were reported with the mean value of 3.37 which is high. The data indicates that the majority of the respondents' agreement on the idea that teachers provide instruction supported by different available instructional materials. The result of the interview as well as practical observation of the actual classroom practices did not witness this reality. In line with this, Rivers (1968) suggested that teachers must use available teaching materials during instruction to provide the learner with concrete experience to arise their interest and to increase their retention of the lesson.

As it is indicated in Table 4, for item no 5 , the majority of the respondents did not show the agreement. The mean value for this item was 2.49 which is relatively low.
Sci. Technol. Arts Res. J., Oct-Dec 2015, 4(4): 194-199

Therefore, from this data one can conclude that most of the respondents have claimed that their teachers do not allow wait time after posing questions. Classroom observation also confirmed that most of the teachers pose questions to the learners and seek quick response from them without providing the necessary time. Contrary to this practice, however, scholars pointed out that increasing weight time leads to longer and higher quality students' response and participation by greater number of students.

To no 6 of Table 4, most of the respondents do not report positively. The mean value for this item was 1.99 . Therefore, as the data clearly indicates, majority of the respondents replied that teachers do not provide sufficient assistance for each individual learner during instruction. Besides, as the observation result shows, even though most of the teachers provide different instructional activities or tasks to their learners as observed, they were not giving much support each individual learner during instruction. However, as Jonassen (1999) suggested, teachers need to conduct continuous follow up on each individual learner and should assist him /her using a variety of forms including questions, prompts, suggested tasks, challenges and other classroom activities.

As indicated in Table 5, 75 (84.6\%) of the respondents answered "Yes "where as the other 14(15.7\%) of the respondents responded "No" regarding the communication ability. As the data shows, most of the respondents reported that their inability to communicate using English language has a negative effect in conducting interactive learning in the classroom.

Table 5: Students' response about the factors affecting the implementation of constructivist teaching approach

\begin{tabular}{lllll}
\hline No & \multicolumn{1}{c}{ Question } & \multicolumn{2}{c}{$\begin{array}{c}\text { No of } \\
\text { respondents }\end{array}$} & $\begin{array}{c}\% \text { of } \\
\text { respondents }\end{array}$ \\
\hline \multirow{2}{*}{1} & $\begin{array}{l}\text { Do you think that your communication ability using the medium of instruction } \\
\text { (i.e. English) is a problem to the implementation of the constructivist teaching } \\
\text { approach? }\end{array}$ & 75 & Yes & $84.6 \%$ \\
\cline { 2 - 5 } & 14 & No & $15.7 \%$ \\
\hline
\end{tabular}

\section{Presentation and Analysis of Data Obtained through Observation}

The classroom observation result indicates that majority of the activities expected to be practiced by the teachers were not observed. For instance, $100 \%$ of the observed classes did not show the use of different instructional approach to implement constructivist teaching approach. In the interview conducted with the teachers, some of the teachers confirmed that applying all the activities in classroom is difficult. This indicates that the teachers implement the traditional/teacher fronted approach to teaching. The reasons for not applying the activities may be lack of training on constructivist teaching approach and classroom conditions such as large class size, inadequate resources and fixed desks.

\section{Presentations and analysis of Data Obtained through Interview}

The interview with the teachers and students examined how the teachers perceive constructivist teaching approach and the problem hindering its implementation. General affective statements indicating positive feelings towards constructivist teaching approach measured individual's perceptions. Perception plays a great role to facilitate or hinder individual's activity. According to Morgan, et al, (1986) perception of an individual refers to the way any event in the world and the world itself looks sounds, feels, tastes or smells to a person. Therefore, it seems apparent that teachers' perception of constructivist teaching approach has an important role in influencing the effective implementation of active learning in the classroom either positively or negatively. These conditions were highlighted in the interview conducted with the teachers' group about their perception on constructivist teaching approach. There were five teachers who participated in detailed interview. They perceived the constructivist teaching approach positively even though they did not employ it effectively in their classroom.

\section{Presentation and Analysis of Data Obtained through Focus Group Discussions}

With regard to the question" how do you see the CTA in making the learners effective"? Almost all the participants of focus group discussion revealed that they have better understanding about CTA. All the participants also disclosed the idea saying that the CTA is an effective teaching approach to develop the physical, mental potential and problem solving capacities of the learners.

To the question "What are the barriers to implement constructivist teaching approach in your school"? 


\section{Solomon Melesse and Endalew Jirata}

Teachers' responses of all the FGDs members indicated that there were powerful impediments working against their acceptance of CTA and most of the constraints they face were external. All the members generally agreed that lack of resources (facilities), large class size, arrangement of desks, lack of supplementary materials, students' English abilities and their low level of motivation to learn, students' expectations, the textbook, students' discipline and lack of appropriate teacher training provisions were the most common problems that act against the effective implementation of CTA. As a result, most students do not understand what the teacher is saying and the relationship between the teacher and students at the back row becomes loose.

The other point FGDs members were raised that, the students do not consider they are learning. This is true especially when they wanted the students to be in groups. Teacher of English department head said, "It makes the students feel that the class itself is monotonous and that they feel I am joking on them." He went on saying, "The students assume they are learning when they are exposed to something on the blackboard.... However, present day language teaching and learning is far from this." Related to this, all the FGDs members described, "The majority of the students expected their lessons to emphasis memorizing than the skills". "They don't feel free when they are assigned to do activities, and in that environment we don't feel we can comfortably traditional teaching in class". This implies that lack of students' interest in the connections of CTA and large class sizes are the major problem that hindering constructivist teaching approaches in the actual classroom.

\section{CONCLUSIONS}

Student centered teaching approach, consisting its effectiveness in equipping students so that they will become problem solvers of themselves and the society at large, was given due attention in the education and training policy implementation strategic documents of Ethiopia. To bring this into effect, both the newly trained and assigned teachers and those teachers already in service were provided some opportunities so that they would become familiar with innovative ideas.

Based on the major findings, the following conclusion was drawn, the analysis of the data indicates that almost all of the participants of the study have perceived constructivist teaching approaches positively. However, perception varies between the teachers. Moreover, it was indicated that the teachers were assured that when they use constructivist teaching approaches, the students learn better and develop the ability to express their feelings confidently; they believe that constructivist teaching approaches play an important role in developing selfconfidence; and those teachers who developed negative feeling towards constructivist teaching approach responded that constructivist teaching approach adds more work and requires additional effort. The analysis of the data disclosed that the extents of the practices of constructivist teaching approaches in the schools were found to be low. The teachers confirmed that they practice constructivist teaching approaches in their classrooms "sometimes", which leads to the conclusion that the practices of constructivist teaching approaches are low.
Sci. Technol. Arts Res. J., Oct-Dec 2015, 4(4): 194-199

The majority of the teachers asserted that students' lack of interest in participating in CTA greatly affected the implementation of CTA in their classrooms; other factors suggested as problems for the effective implementation of CTA were shortage of time and lack of resources, work load, students language deficiency and large class size was also indicated as the major problem in implementing CTA.

\section{Conflict of Interest}

Conflict of interest none declared.

\section{REFERENCES}

Brooks, J.G. and Brooks, M.G. (1992). The case for constructivist classrooms. Alexandria via: Association for supervision and curriculum Development. http://www.ascd.org/publications/books/199234.aspx Accessed on 05 Aug 2015.

Brophy, J. (1989). Advances in research on teaching (vol. 1) London: Jai press

Curick Shank D.C (1995). The Art of Teaching. New York: McGraw Hill Inc.

Davies, I.K. (1981). Motivation and Education. A look at some important consequences, New York: McGraw Hill Inc.

Derebsa, Dufera. (2004) .Fundamental of curriculum Development. Addis Ababa :( Unpublished).

Dewey, J. (1983). How we think. A Restatement of the Reflection of Reflective Thinking to the Educative process .Boston: DC. Heath.

Goge, N.L (1978). The scientific basis for the art of teaching. New York: Teacher college press.

ICDR, (1999). Teachers Education Hand book. Addis Ababa ministry of Educational.

Jonassen, D.H. (1999). Constructing Learning Environment on the web. Engaging Students in Meaningful Learning. Retrieved on May 6/ 2015 from http/Len/org/ constructivist teaching method.

Lea, S., Stephenson, N. and Tory, K. (2003). Higher Education Students Attitude to Student Centered Learning. Beyond Educational Bulimia Studies in Higher Education .New York: McGraw Hill Inc.

MOE, (1994). The New training and Education policy of Ethiopia, Addis Ababa.

Morgan, T.C. (1986). Introduction to Psychology. $\left(7^{\text {th }} \cdot\right.$ ed) New York: McGraw Hill.

Murnane, R.J. and Willet, J.B. (2010). Methods Matter: Improving Causal Inference in Educational and Social Science Research. New York, New York: Oxford University Press.

Piaget, J. (1976) to understand is to invite: The future of the education .New York: penguin.

River Wilga M. (1968). New Design in Teaching of English. Sheraton International Text books.

TESO, (2003) .The National Frame for the Teacher Education System.

UNESCO, (2005) Education for all: The quality importance Pairs: UNESCO 